\title{
"Investment asset allocation in response to tax relief for mutual funds: The case of South Korea"
}

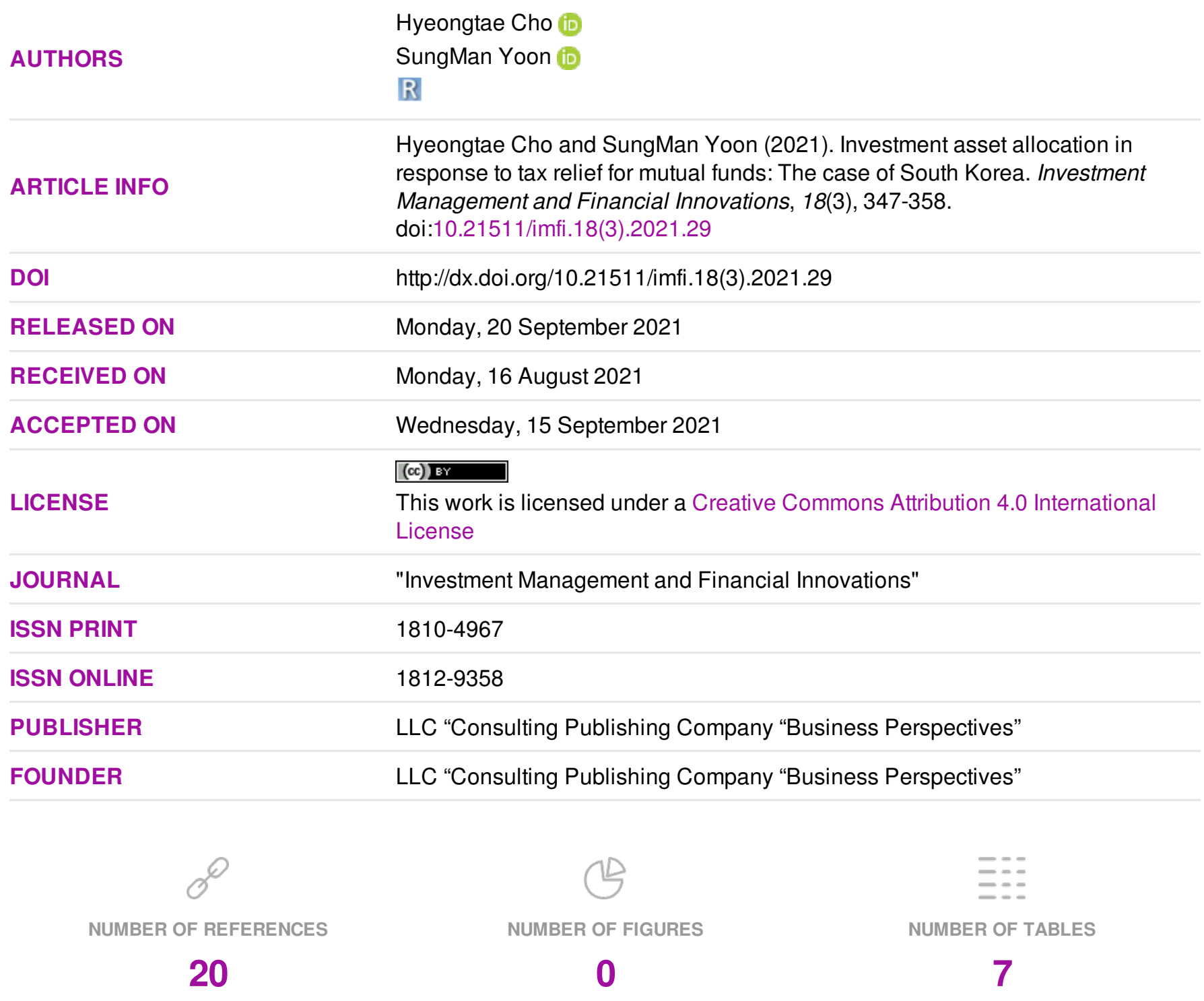

(c) The author(s) 2021. This publication is an open access article. 


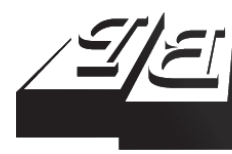

BUSINESS PERSPECTIVES

9

LLC "CPC "Business Perspectives" Hryhorii Skovoroda lane, 10, Sumy, 40022, Ukraine www.businessperspectives.org
Received on: $16^{\text {th }}$ of August, 2021 Accepted on: $15^{\text {th }}$ of September, 2021 Published on: $20^{\text {th }}$ of September, 2021 (c) Hyeongtae Cho, SungMan Yoon, 2021

Hyeongtae Cho, Assistant Professor, College of Business Administration, Hongik University, South Korea.

SungMan Yoon, Professor, Department of Business Administration, Seoul National University of Science \& Technology, South Korea. (Corresponding author)
This is an Open Access article, distributed under the terms of the Creative Commons Attribution 4.0 International license, which permits unrestricted re-use, distribution, and reproduction in any medium, provided the original work is properly cited.

Conflict of interest statement: Author(s) reported no conflict of interest
Hyeongtae Cho (South Korea), SungMan Yoon (South Korea)

\section{INVESTMENT ASSET ALLOCATION IN RESPONSE TO TAX RELIEF FOR MUTUAL FUNDS: THE CASE OF SOUTH KOREA}

\begin{abstract}
This study examines whether the management style of a fund differs depending on the type of fund being managed for tax purposes, given the rules of temporary tax relief for fund investments. The study considers a change in the ratio of tax-favored assets to the net asset value of a tax relief qualified fund around the effective date of tax relief laws in South Korea in 2007 and 2016. A regression model is used to test sample data from domestic and overseas equity funds available in the three months before and after the 2007 and 2016 Restriction of Special Taxation Act came into effect. It was found that the ratio of the value of tax-favored assets to the net asset value in the tax relief qualified fund increased significantly since the enactment of tax relief laws in both 2007 and 2016. These findings suggest that fund managers may try to change the asset allocation in a managed fund to increase the after-tax return of the fund investor, which means that fund managers do take into account the potential tax burden on fund investors and try to minimize it.
\end{abstract}

\section{Keywords \\ dividend tax, tax clientele, asset allocation, fund manager, mutual fund}

JEL Classification G11, H21, H24

\section{INTRODUCTION}

Do mutual fund managers care about tax factors for fund investors? Investors often choose a particular type of business organization or transaction type in order to reduce the tax burden (Scholes et al., 2016). A mutual fund investor entrusts his or her investment to the fund manager to invest in a financial product that can be managed to some extent at the fund manager's discretion. Therefore, the fund manager may have an implicit incentive to maximize the after-tax rate of return by constructing an asset portfolio within the fund in a direction that is advantageous to the fund investor (Ferson \& Mo, 2016; Adcock et al., 2020). In particular, the proportion of tax-favored assets in the fund's asset portfolio is increased if it is composed mainly of assets with a high after-tax return, or if the rate of return is the same (Chan \& Chen, 1992).

A fund is an alternative financial investment instrument wherein a separate collective investment vehicle pools the money of multiple investors, invests it in securities, derivatives, and/or real assets, and then allocates profits to investors according to investment performance ( $\mathrm{Li}$ et al., 2016; Gjergji et al., 2017). It is one of the most prominent financial investment options, along with traditional investments, in South Korea. Under Korean tax law, the income distributed to an individual investor from a fund is generally treated as a dividend and taxed at a higher rate regardless of the investment assets. Only capital gains through funds on South Korean domestically listed shares are excluded from the taxable dividend income. 
Meanwhile, the Korean government introduced the temporary tax exemption law on June 1, 2007, to further exclude capital gains on overseas-listed shares by enforcing Article 91-2 of the Restriction of Special Taxation Act (hereinafter referred to as RSTA 2007). In 2016, approximately ten years after this scheme was put into effect, the government re-implemented a tax amendment similar to RSTA 2007. This scheme was established under Article 91-17 of the Restriction of Special Taxation Act (hereinafter referred to as RSTA 2016), which exempts tax on capital gains (or losses) on overseas-listed shares and related exchange rates earned by residents through qualified funds under the Financial Investment Services and Capital Market Act (FISCMA).

The differential tax treatment on income from fund investments is not common in other countries (Akpanibah \& Ini, 2019). However, South Korea has introduced a lot of temporary tax reliefs on existing fund investment tax laws by using the RSTA for the various policy goals. For example, the aforementioned RSTA 2007 and RSTA 2016 were introduced to help stabilize the exchange (FX) rate of the export-driven South Korean economy.

There are a limited number of studies on the management style of fund managers in which the tax effect on fund investors is considered. In addition, existing studies have not been undertaken in a setting where the tax amendment takes place. Prior studies are limited to the cross-sectional analysis between tax-favored accounts and tax-unfavored accounts under the permanent tax law while reviewing the tax clientele effect on the management of assets in a fund (Christoffersen et al., 2005; Sialm \& Starks, 2012).

In this regard, by utilizing the unique tax amendment in South Korea, this study analyzes whether differences in the tax treatment of income derived from fund investments affect the fund management style of a fund manager when a new temporary tax relief rule is implemented. In particular, it investigates whether there has been any significant change in asset allocation, which is the ratio of the value of tax-favored assets (i.e., overseas-listed shares) to the fund's net asset value (hereinafter referred to as $\mathrm{NAV}$ ), around the period of implementation of the two tax relief rules.

The remainder of this study is organized as follows. Section 1 reviews the literature on the effects of the tax clientele on a manager's fund management and Korean tax reform for investment in funds. Also, in Section 1, hypotheses are developed based on the literature review. Section 2 explains the research methods, including a research model, variables and sample selection. Section 3 provides the results of the empirical test and the discussion on the test results. The final section provides conclusions.

\section{LITERATURE REVIEW}

Previous studies document that fund management may be affected by taxation rules around fund investment. Sialm and Zhang (2020) provided empirical evidence that the performance of equity mutual funds has a relationship with their tax burden. They found that tax-efficient funds show not only better after-tax performance but also better before-tax performance owing to better selectivity. They also provide a theoretical perspective that the size of the tax clientele affects the equilibrium performance of mutual funds. Guan et al. (2008) demonstrated that managerial ability affects the tax-efficient dividend policies, increasing the sensitivity of dividends to the dividend tax penalty.
They also found that the positive relationship between managerial ability and the shareholder tax sensitivity of dividends decreases in institutional ownership. Sialm and Starks (2012) argued that tax preferences of mutual fund clientele influence the investment strategies of fund managers. They found that mutual funds that were held mainly by taxable investors have a tendency to be more tax-efficient than those held primarily by defined contribution investors. Specifically, they found that funds that were held extensively by tax-qualified defined contribution plans have a tendency to have lower expense ratios and greater assets under management compared to funds with lower-defined contributions assets. Desai and Dharmapala (2007, 2011) investigated how dividend taxes in- 
fluence portfolio choices in the United States, reviewing the response to the tax treatment of foreign dividends in the Jobs and Growth Tax Relief Reconciliation Act (JGTRRA) of 2003, which applied a reduced tax rate on qualified foreign corporations. They found that more US equity holdings were reallocated towards affected countries by the JGTRRA, compared to unaffected countries. Christoffersen et al. (2005) explored how fund managers deal with the conflicting preferences of their investors by focusing on the conflict between taxable and retirement accounts of international funds. They found evidence that managers with more retirement money follow the preferences of retirement investors. Fong et al. (2009) examined whether asset sales are timed to take advantage of the introduction of substantial discounts to realize capital gains when the holding period to pursue tax efficiency is at least one year. They found that, generally, active fund managers significantly increased the realization of long-term capital gains after the change in tax laws.

There are also a couple of studies to document that fund management may affect other aspect around the fund management. Gjergji et al. (2017) demonstrated that financial advisers provide useful tax advice to their clients. The researchers analyzed two categories of investors; those who make a direct investment in shares and those who purchase mutual fund shares through financial advisers. They found that the latter exhibit a stronger tendency towards avoiding taxable distributions than the former. Bergstresser and Porteba (2002) examined the relationship between the after-tax returns on equity mutual funds and the following cash inflows to these funds; they presented evidence showing that the after-tax returns are better than pre-tax returns in explaining inflows. Sialm and Tham (2016) investigated spillover effects across business segments. They showed that the reputation of a fund management's brand significantly affects the behavior of its customers. They also provide empirical evidence that flows into funds increase with the prior share price performance of the fund management companies

A few other Korean studies show that fund investors consider tax factors when investing in mutual funds. Yoon (2014) analyzed whether cash flows to funds changed through tax incentives around the implementation and end periods of the temporary tax exemption rule under RSTA 2007. Yoon (2014) confirmed that the sale of foreign funds and cash flows to foreign funds after enforcement of the rule significantly increased compared to that prior to the enforcement. In addition, sales and cash flows were determined to decline significantly after expiration of the temporary law. Cho (2018) provided empirical evidence that net cash flows to overseas equity funds increased significantly after the enactment of RSTA 2016, compared to domestic equity funds. Cho and Yoon (2016) and Yoon and Kim (2015) provide empirical evidence that, compared to general fund managers, pension fund managers tend to employ fund management strategies that do not focus on the reduction of the tax burden on fund investors. They argue that this may be attributed to the fact that an income distributed from a general fund to an individual is treated as a dividend, whereas an income from qualified pension accounts is treated as pension income.

Under the Korean Individual Income Tax Act, in general, any income received by an individual from fund investment is treated as a dividend and taxed at $15.4 \%$. Only capital gains through funds on South Korean listed shares are excluded from taxable dividend income.

However, for various purposes, including the stabilization of the South Korean domestic foreign exchange market, the government implemented the temporary tax exemption rule on June 1, 2007, to temporarily further exempt capital gains on overseas-listed stocks by enforcing RSTA 2007. The tax exemption of capital gains on overseas-listed stocks is allowed for South Korean onshore funds, under the Indirect Investment Assets Management Business Act (hereinafter referred to as IIAMBA).

In 2016, approximately ten years after the foregoing scheme, the government re-implemented a tax amendment similar to RSTA 2007. This scheme was established under RSTA 2016, which temporarily further exempts tax on capital gains (or losses) on overseas-listed shares and related exchange rates earned by residents through qualified funds under the Financial Investment Services and Capital Market Act (hereinafter referred to as FISCMA). Table 1 compares the two tax systems. 
Therefore, under the two temporary tax exemptions, a fund investor may save taxes arising from capital gains on investment in overseas-listed shares through the fund after the implementation of the tax relief rule. Accordingly, if fund managers consider these temporary tax exemption rules in the interest of fund investors, they may increase their exposure to tax-favored assets (i.e., overseas shares) in their fund portfolio to increase investors' after-tax rate of return.

Table 1. Comparison of RSTA 2007 and RSTA 2016

\begin{tabular}{|c|c|c|}
\hline Item & RSTA 2007 & RSTA 2016 \\
\hline $\begin{array}{l}\text { Qualifying } \\
\text { fund }\end{array}$ & $\begin{array}{l}\text { Overseas equity } \\
\text { fund under } \\
\text { IIAMBA }\end{array}$ & $\begin{array}{l}\text { Overseas equity fund under } \\
\text { FISCMA }\end{array}$ \\
\hline $\begin{array}{l}\text { Investment } \\
\text { amount } \\
\text { capped }\end{array}$ & None & KRW 30 million per taxpayer \\
\hline $\begin{array}{l}\text { Account } \\
\text { requirement }\end{array}$ & $\begin{array}{l}\text { There is no } \\
\text { requirement for } \\
\text { an investor to } \\
\text { hold an account }\end{array}$ & $\begin{array}{l}\text { An investor must make new } \\
\text { investments in a new fund } \\
\text { or an existing fund via an } \\
\text { exclusive account provided by } \\
\text { a fund distributor (e.g., bank, } \\
\text { brokerage firm, etc.) }\end{array}$ \\
\hline $\begin{array}{l}\text { Non-taxable } \\
\text { profit }\end{array}$ & $\begin{array}{l}\text { Capital gains } \\
\text { (or losses) on } \\
\text { overseas-listed } \\
\text { shares invested } \\
\text { by the fund }\end{array}$ & $\begin{array}{l}\text { Capital gains (or losses) } \\
\text { on overseas-listed shares } \\
\text { invested by the fund and } \\
\text { related foreign exchange rates }\end{array}$ \\
\hline $\begin{array}{l}\text { Application } \\
\text { time }\end{array}$ & $\begin{array}{l}\text { June } 1,2007, \text { to } \\
\text { December } 31 \\
2009\end{array}$ & $\begin{array}{c}\text { February 26, 2016, to } \\
\text { December 31, } 2017\end{array}$ \\
\hline
\end{tabular}

Most previous studies on the effect of taxation on funds have been heavily concentrated on the relationship between fund investors' tax clientele and issues surrounding fund performance. In addition, the literature has focused on cross-sectional analyses by comparing taxable accounts to non- taxable (or less-taxable) accounts. Few studies have dealt with whether the tax clientele or taxation on fund investors has an impact on fund managers' decision-making on the allocation of investment assets in funds. The purpose of this study is to provide further evidence on whether the asset portfolio in a fund may be changed owing to tax amendments that are applicable on a temporary basis. By doing this, this study tries to distinguish itself from prior literature because it directly reviews changes in asset allocation determined by a fund manager.

According to the review of previous studies and as per Korean taxation rules, a fund manager who manages a dividend-generating fund may attempt to increase their exposure to overseas-listed shares by considering investors' tax preferences. In other words, to maximize after-tax returns for fund investors, the fund manager makes more investment into overseas-listed shares. This study, therefore, develops the following hypotheses:

H1: The ratio of overseas-listed shares to fund $N A V$ is higher after the implementation of RSTA 2007.

H2: The ratio of overseas-listed shares to fund $N A V$ is higher after the implementation of RSTA 2016.

This study focuses on the shift of asset allocation in the implementation of the two temporary tax exemption rules, not sunset of rules, for the following reasons. First, seasonal effects, such as the January effect, may influence fund managers' decisions. Both RSTA 2007 and RSTA 2016 expired on December 31, as explained in Table 1. Hence, when comparing asset allocations around the year-end, it may be difficult to disentangle the effect of considering tax relief for investors from the seasonal effects, if fund managers invest more shares in January and sell further in December. In addition, the window dressing effect may be involved at the end of the year. If a window dressing strategy is executed by a portfolio manager near the year-end to manipulate fund performance, the effect may blur the portfolio decision to be made by the fund manager. Second, with respect to RSTA 2016, an individual investor has a capped investment of KRW 30 million to take tax exemption benefit, as presented in Table 1. Therefore, there is no incentive for the investor to invest further in the fund near the sunset, if the individual investor already makes the investment up to the limit at the middle point of the period when RSTA 2016 is applicable. This investment limit rule may affect fund managers' decision-making before the sunset of RSTA 2016.

\section{METHOD}

This study examines whether a fund manager changes the portfolio by considering a change in fund taxation. In other words, it empirically analyzes whether a fund manager increases the exposure to certain assets in the portfolio when 
the assets are tax-favored under newly implemented rules. This assumption is based on the review of various prior studies that provide empirical evidence that a tax manager manages a portfolio by considering the tax preference of investors. Accordingly, under RSTA 2007 and RSTA 2016, a fund manager is expected to increase exposure to tax-favored assets (i.e., overseas-listed shares) after the implementation of the tax relief rules.

To test this hypothesis, this study uses the research model developed by Cho and Yoon (2016) to determine the ratio of equity to total assets in a managed fund. For test purposes, this study will employ a difference-in-differences model to measure the significance of a change in the asset allocation of an overseas equity-type fund by comparing the portion of shares to overseas equity-type fund's NAV with the portion of domestic shares to domestic equity-type fund's NAV. This study also expands the existing regression model by including benchmarked return followed (BM), and Sharpe ratio to strengthen test results. For test purposes, this study has multiple test periods with key dates (the enactment date) at the midpoint of the test periods.

Empirical analyses are conducted and test results are provided around the effective dates (June 1, 2007 and March 1, 2016), which are two months (Period 1 - H1: May 1, 2007 to June 30 2007, H2: February 1, 2016 to March 31, 2016), four months (Period 2 - H1: April 1, 2007 to July 31, 2007, H2: January 1, 2016 to April 30, 2016), and six months (Period 3 - H1: March 1, 2007 to August 31, 2007, H2: December 1, 2015 to May 31, 2016), as performed by prior research.

$$
\begin{aligned}
& \text { EQUITY } \text { Ratio }_{i t}=\beta_{0}+\beta_{1} E X E M P T_{t}+ \\
& +\beta_{2} \text { FOREIGN }_{i}+\beta_{3} \text { EXEMPT } \cdot \text { FOREIGN }+ \\
& +\beta_{4} \text { RETURN }_{i, t}+\beta_{5} \text { RISK }_{i, t}+\beta_{6} \operatorname{SIZE}_{i, t}+ \\
& +\beta_{7} F E E_{i, t}+\beta_{8} A G E_{i, t}+\beta_{9} B I G_{i, t}+ \\
& +\beta_{10} F X_{t}+\beta_{11} B M_{i, t}+\beta \sum \text { Oper }+\varepsilon_{i, t} \\
& \text { EQUITY_Ratio }{ }_{i t}=\beta_{0}+\beta_{1} E_{\text {EXMPT }}+ \\
& +\beta_{2} \text { FOREIGN }_{i}+\beta_{3} \text { EXEMPT } \cdot \text { FOREIGN }+ \\
& +\beta_{4} \text { RETURN }_{i, t}+\beta_{5} \text { RISK }_{i, t}+\beta_{6} \text { SIZE }_{i, t}+ \\
& +\beta_{7} F E E_{i, t}+\beta_{8} A G E_{i, t}+\beta_{9} B I G_{i, t}+\beta_{10} F X_{t}+ \\
& +\beta_{11} B M_{i, t}+\beta_{12} \text { Sharpe }_{i, t}+\beta \sum \text { Oper }+\varepsilon_{i, t} \text {. }
\end{aligned}
$$

The final samples consist of 22,648 fund-week observations for the test period of Hypothesis 1 and 153,517 fund-week observations for the test peri-

od of Hypothesis 2, respectively. Table 3 presents

where EQUITY_Ratio $=$ the ratio of equity to asset value in a fund; EXEMPT = indicator variable set to 1 for the period after the date of the implementation, and 0 otherwise; FOREIGN = indicator variable set to 1 for overseas equity fund and 0 for domestic equity fund; EXEMPT $\cdot$ FOREIGN $=$ the interaction term of EXEMPT and FOREIGN is set to 1 for overseas equity funds during the period after the implementation of RSTA 2007 or 2016; RETURN = the weekly rate of return of a fund; RISK = risk to a fund, standard deviation of the rate of return of a fund; SIZE = natural logarithm of fund initial NAV; $F E E$ = total fees for investment in funds; $A G E$ = number of years elapsed from the inception of a fund; $B I G$ = indicator variable set to 1 for Big 5 Asset Management Company, or 0 otherwise; $F X=$ change in the foreign exchange rate (KRW against USD); $B M=$ benchmarked return followed by a fund; Sharpe $=$ Sharpe ratio of funds.

The benchmark rate of returns from the fund database (FnSpectrum) is provided in Table 2. Domestic equity type funds take a benchmark rate of return, including KOSPI TR, MKF Small and mid-size, KOSPI 200 TR. In addition, Overseas equity type funds have a benchmark rate of return such as MSCI ACWI, MSCI EM, MSCI EUROPE, MSCI EM EUROPE, MSCI NORTH AMERICA, MSCI EM LATIN AMERICA, MSCI ARABIAN MARKETS \& AFRICA, MSCI AC ASIA PACIFIC, and MSCI EM ASIA.

To analyze the effect of the tax factor on the portfolio decision, fund samples are selected to meet the following conditions:

1) Domestic and overseas equity funds available for a period of three months before and after the enforcement under RSTA 2007 (June 1, 2007) and RSTA 2016 (March 1, 2016).

2) Funds with data for variables (e.g., the ratio of shares to NAV) available in FnSpectrum, which is a fund database in Korea. 
Table 2. The benchmark rate of return

\begin{tabular}{|c|c|c|}
\hline Class 1 & Class 2 & Benchmark \\
\hline \multirow{8}{*}{ Domestic equity } & Active stock general & KOSPI TR \\
\hline & Active stock small and mid-size & MKF Small and mid-size \\
\hline & Active stock dividend & KOSPI TR \\
\hline & Active stock sector & KOSPITR \\
\hline & Active stock theme & KOSPI TR \\
\hline & Index stock KOSPI 200 & KOSPI 200 TR \\
\hline & Index stock sector & KOSPI TR \\
\hline & Index stock other & KOSPI TR \\
\hline \multirow{9}{*}{ Overseas equity } & Global sector & $\mathrm{MSCl} \mathrm{ACWI}$ \\
\hline & Emerging countries stock & $\mathrm{MSCI} E M$ \\
\hline & Europe stock & MSCI EUROPE \\
\hline & Emerging Europe stock & MSCI EM EUROPE \\
\hline & North America stock & MSCI NORTH AMERICA \\
\hline & Middle South America stock & MSCI EM LATIN AMERICA \\
\hline & Middle East Africa stock & MSCI ARABIAN MARKETS \& AFRICA \\
\hline & Asia Pacific stock & $\mathrm{MSCI} A C$ ASIA PACIFIC \\
\hline & Emerging Asia stock & $\mathrm{MSCl}$ EM ASIA \\
\hline
\end{tabular}

numbers of domestic equity funds and foreign equity funds in the samples for testing the two hypotheses.

Table 3. Size of sample funds

\begin{tabular}{l|c|c}
\hline \multicolumn{1}{c}{ Type } & H1 (RSTA 2007) & H2 (RSTA 2016) \\
\hline Domestic equity fund & 732 & 2,971 \\
\hline Foreign equity fund & 264 & 3,460 \\
\hline Total & 996 & 6,431 \\
\hline
\end{tabular}

\section{RESULTS}

Table 4 presents descriptive statistics of variables used to test Hypothesis 1 for RSTA 2007 and Hypothesis 2 for RSTA 2016. Due to space limitations, this study presents the descriptive statistics in Model 3 for the six-month periods around the implementation of the two tax amendments.

Tables 4 shows that the means of the dependent variable are lower than the medians, showing a left-skewed distribution for both RSTA 2007 and RSTA 2016. In test samples for RSTA 2007, Risk, Size, and Fee have means lower than medians, showing left-skewed distributions. Meanwhile, in test samples for RSTA 2016, Return and Size have means lower than medians, showing left-skewed distributions.

EQUITY_Ratio in RSTA 2016 is found to be lower than EQUITY_Ratio in RSTA 2007. This may be attributed to the following reasons. First, an ex- isting overseas equity fund was qualified for tax benefits under RSTA 2007, whereas an existing equity fund was not necessarily RSTA 2016 compliant. Under the RSTA 2016, investors are required to invest in an existing fund or a new fund via a qualified exclusive account provided by a fund distributor to obtain a tax benefit. Hence, a fund manager may be required to launch new funds to be eligible for tax benefits under RSTA 2016. As a result, it was likely that a fund manager created new funds with no or less investment in shares in the early stage of RSTA 2016. Second, there was a big dispute between tax authorities and taxpayers on how to calculate tax benefits under RSTA 2007 around the end of 2008, when a financial crisis took place. The legal dispute was long dragged and finalized by a Supreme Court decision (Supreme Court 2013du6107) at the end of 2015. In the process of incorporating the result of the court case into RSTA 2016, the confirmation of the enforcement decree on the tax relief has been long-delayed and may potentially prevent a fund manager from investing in shares. Those tax benefit calculation uncertainties might make a fund manager feel uncomfortable in investing shares in the early stage of RSTA 2016.

To verify the aforementioned hypotheses, this study first conducts a t-test for the enforcement of RSTA 2007 (June 1, 2007) and RSTA 2016 (March $1,2016)$. Table 5 presents a statistical comparison of the ratio of the value of domestic shares and overseas shares to fund NAV in domestic equity 
Table 4. Descriptive statistics of major variables for RSTA 2007 and 2016

\begin{tabular}{|c|c|c|c|c|c|c|c|c|}
\hline \multirow{2}{*}{ Variable } & \multicolumn{4}{|c|}{ RSTA $2007(n=22,648)$} & \multicolumn{4}{|c|}{ RSTA $2016(n=153,517)$} \\
\hline & Mean & Std. Err. & Min & Max & Mean & Std. Err. & Min & Max \\
\hline EQUITY_Ratio & 86.633 & 19.054 & 0.001 & 100 & 74.477 & 32.553 & 0 & 100 \\
\hline EXEMPT & 0.545 & 0.498 & 0 & 1 & 0.565 & 0.496 & 0 & 1 \\
\hline FOREIGN & 0.231 & 0.422 & 0 & 1 & 0.519 & 0.5 & 0 & 1 \\
\hline RETURN & 0.602 & 3.298 & -17.743 & 51.153 & -0.075 & 2.669 & -26.256 & 17.446 \\
\hline RISK & 7.636 & 8.405 & 0 & 97.565 & 17.543 & 9.412 & 0 & 83.895 \\
\hline SIZE & 24.141 & 2.243 & 11.503 & 28.452 & 20.824 & 3.434 & 0.693 & 28.79 \\
\hline FEE & 1.259 & 0.846 & 0 & 2.68 & 1.123 & 0.73 & 0 & 2.883 \\
\hline$A G E$ & 10.147 & 1.849 & 8 & 17 & 4.471 & 3.786 & 0 & 17 \\
\hline$B I G$ & 0.426 & 0.495 & 0 & 1 & 0.428 & 0.495 & 0 & 1 \\
\hline$F X$ & 0 & 0.006 & -0.01 & 0.022 & 0.001 & 0.014 & -0.032 & 0.023 \\
\hline$B M$ & 0.518 & 3.2 & -16.545 & 19.292 & 0.102 & 2.448 & -10.273 & 23.577 \\
\hline Sharpe & 1.131 & 1.538 & -7.683 & 8.492 & -3.204 & 5.931 & -17.213 & 3.104 \\
\hline
\end{tabular}

Note: EQUITY Ratio = the ratio of equity to asset value in a fund; EXEMPT = indicator variable set to 1 for the period after the date of the implementation, and 0 otherwise; FOREIGN = indicator variable set to 1 for overseas equity fund and 0 for domestic equity fund; RETURN = the weekly rate of return of a fund; RISK = risk to a fund, standard deviation of the rate of return of a fund; SIZE = natural logarithm of fund initial NAV; FEE = total fees for investment in funds; $A G E=$ number of years elapsed from the inception of a fund; BIG = indicator variable set to 1 for Big 5 Asset Management Company, or 0 otherwise; $\mathrm{FX}=$ change in the foreign exchange rate (KRW against USD); $\mathrm{BM}=$ benchmarked return followed by a fund; Sharpe = Sharpe ratio of funds.

funds and overseas equity funds around the enforcement of RSTA 2007 (June 1, 2007) and RSTA 2016 (February 29, 2016).

With respect to the tests of the ratio of equities to NAV around the enforcement of RSTA 2007, overseas equity funds show an increased equity portion in NAV after the enforcement date (June $1,2016)$. The same results were obtained from the tests for Periods 1, 2, and 3. These findings mean that an overseas equity fund manager increases exposure to the emerging tax-favored asset, which is overseas equity, in his/her portfolio after the enforcement of RSTA 2007. This may be interpreted as follows: a fund manager considers a fund investor's after-tax return and tries to take advantage of tax-saving opportunities for fund investors if there is any tax amendment to provide such opportunities.

This study finds the same pattern around the enforcement of the RSTA 2016. After this enforcement, the ratio of overseas equity value in overseas equity funds mostly increased significantly, whereas the ratio of domestic equity value in domestic equity funds decreased significantly. However, during Period 1, the increase in overseas equity exposure was not significant. This may be attributed to the following facts. First, for investors to receive tax relief from fund investments, they are required to make an investment via ex- clusive accounts provided by fund distributors. In this regard, a considerable number of fund managers launch new funds to fit the account requirements around the enforcement date, which does not give sufficient time for fund managers to make investment decisions. Second, the delay in the confirmation of the enforcement decree might make fund managers feel uncomfortable in making investment decisions shortly after RSTA 2016, given the legal dispute on tax relief from RSTA 2007.

Tables 6 and 7 present the results of the multivariate regression analyses testing Hypotheses 1 and 2 by employing the difference-in-differences model for the samples of domestic and overseas equity funds. This analysis aims to analyze whether the temporary tax exemption rules (i.e., RSTA 2007, RSTA 2016) influence asset allocation decisions to be made by a fund manager in a fund, given that the rules give tax relief on investment in certain assets (i.e., overseas-listed shares) via a fund. This study compares the equity exposure in the qualifying funds with those to the domestic equity funds ineligible for tax relief under RSTA 2007 and RSTA 2016.

In Table 6, for the RSTA 2007 enforcement, the interaction variable for FOREIGN and EXEMPT has a positive coefficient $(2.184(p<0.1) \sim 4.326(p$ $<0.01)$ ) at the significance level for all the tested periods (i.e., Period 1, Period 2, and Period 3). This 
Table 5. $t$-test results for overseas equity and domestic fund

\begin{tabular}{|c|c|c|c|c|c|c|c|}
\hline \multirow{2}{*}{ Period } & \multirow{2}{*}{ Fund type } & \multicolumn{2}{|c|}{ Before implementation } & \multicolumn{2}{|c|}{ After implementation } & \multirow{2}{*}{$\begin{array}{c}\text { Mean } \\
\text { difference }\end{array}$} & \multirow{2}{*}{$t$-stat. } \\
\hline & & Mean & Std. Err. & Mean & Std. Err. & & \\
\hline \multirow{2}{*}{ Period 1_2007 } & Overseas & 80.2242 & 0.6179 & 81.6087 & 0.4581 & 1.3845 & $1.8355^{*}$ \\
\hline & Domestic & 89.0506 & 0.3045 & 88.4500 & 0.3460 & -0.6006 & -1.2991 \\
\hline \multirow{2}{*}{ Period 2_2007 } & Overseas & 80.7083 & 0.4464 & 82.3843 & 0.3240 & 1.6759 & $3.1087^{* * *}$ \\
\hline & Domestic & 88.9189 & 0.2266 & 88.3432 & 0.2600 & -0.5756 & $-1.6588^{*}$ \\
\hline \multirow{2}{*}{ Period 3_2007 } & Overseas & 80.1457 & 0.3811 & 83.0966 & 0.2605 & 2.9509 & $6.6076^{* * *}$ \\
\hline & Domestic & 88.5288 & 0.1925 & 87.5940 & 0.2251 & -0.9348 & $-3.1248^{* * *}$ \\
\hline \multirow{2}{*}{ Period 1_2016 } & Overseas & 68.9643 & 0.4343 & 69.1118 & 0.3072 & 0.1475 & 0.2814 \\
\hline & Domestic & 93.2775 & 0.0974 & 91.4036 & 0.0910 & -1.8738 & $-13.9820^{* * *}$ \\
\hline \multirow{2}{*}{ Period 2_2016 } & Overseas & 68.2797 & 0.2657 & 69.5008 & 0.2107 & 1.2211 & $3.6369 * * *$ \\
\hline & Domestic & 91.9062 & 0.0685 & 91.3710 & 0.0633 & -0.5351 & $-5.7408^{* * *}$ \\
\hline \multirow{2}{*}{ Period 3_2016 } & Overseas & 68.3300 & 0.2270 & 70.0082 & 0.1761 & 1.6781 & $5.9063^{* * *}$ \\
\hline & Domestic & 91.5801 & 0.0590 & 91.2932 & 0.0544 & -0.2869 & $-3.5730^{* * *}$ \\
\hline
\end{tabular}

Notes: Period 1_2007 = May 1, 2007 to June 30, 2007; Period 2_2007 = April 1, 2007 to July 31, 2007; Period 3_2007 = March 1, 2007 to August 31, 2007; Period 1_2016 = February 1, 2016 to March 31, 2016; Period 2_2016 = January 1, 2016 to April 30, 2016); Period 3_2016 = December 1, 2015 to May 31, 2016). ***, ** and * indicate statistical significance at the 1\%, 5\%, and $10 \%$ two-tailed level, respectively.

means that more overseas equity fund assets have been allocated to equity, compared to the domestic equity fund after the implementation of RSTA 2007. Fund managers of overseas equity funds are perceived to have made more investments in overseas equity to provide tax benefits to fund investors after the enforcement of RSTA 2007. This result may provide empirical evidence that fund managers care about fund investors' tax burden and try to maximize investors' after-tax returns by allocating fund assets to tax-favored assets.

With respect to control variables for testing Hypothesis 1, RETURN, SIZE, FEE and BIG have positive correlations with EQUITY_Ratio. These relations may suggest that funds with big size, high returns, large asset managers or high fees tend to have more equity investments during the test period for Hypothesis 1. Meanwhile, AGE has a negative relationship with the dependent variable. This may be interpreted to mean that fund managers operating new funds make more equity investments, suggesting that they manage investment assets more aggressively than older funds.

Similar results were obtained when the test was conducted for the enforcement of RSTA 2016, as presented in Table 7. For Periods 2 and 3, the interaction variables of FOREIGN and EXEMPT have positive coefficients $(1.27 \sim 1.76, \mathrm{p}<0.01)$ at a significant level. These results are in line with the test results of RSTA 2007; overseas equity expo- sure in overseas equity funds increased after the enforcement of the tax exemption rule, compared to domestic equity exposure in domestic equity funds. Fund managers were likely attracted to shift their portfolio focus to tax-favored assets to provide fund investors with tax-saving opportunities arising from RSTA 2016. This may imply that fund managers consider fund investors' after-tax returns when making investment decisions. With respect to the test result during Period 1, this study failed to find any significance for the coefficient of the interaction variable. This may be due to the low equity investment by fund managers around the enforcement of RSTA 2016, given the newly launched overseas funds and the delayed announcement of the enforcement decree, as explained in the previous section.

For control variables used for testing Hypothesis 2, like testing Hypothesis 1, SIZE, FEE and BIG have positive correlations with EQUITY_Ratio. These findings indicate that funds with big size, large asset managers or high fees may hold more equity investments during the test period for Hypothesis 2. On the other hand, AGE also has a positive relationship with EQUITY_Ratio, which is different from the finding in Hypothesis 1 . This may be attributed to the fact that there are more funds newly launched for RSTA 2016 during the test period and fund managers may be cautious about investing in stocks due to the perceived tax uncertainty arising from RSTA 2007. 
Table 6. Regression results: RSTA 2007

\begin{tabular}{|c|c|c|c|c|c|c|}
\hline \multirow{2}{*}{ Variables } & \multicolumn{2}{|c|}{ Period 1} & \multicolumn{2}{|c|}{ Period 2} & \multicolumn{2}{|c|}{ Period 3} \\
\hline & Model 1 & Model 2 & Model 1 & Model 2 & Model 1 & Model 2 \\
\hline \multirow{2}{*}{ EXEMPT } & -0.629 & -0.411 & $-0.650^{*}$ & -0.615 & $-0.858^{* *}$ & $-1.289 * * *$ \\
\hline & $(0.467)$ & $(0.491)$ & $(0.330)$ & $(0.362)$ & $(0.293)$ & $(0.307)$ \\
\hline \multirow{2}{*}{ FOREIGN } & $-10.82^{* * *}$ & $-10.85^{* * *}$ & $-10.25^{* * *}$ & $-10.24 * * *$ & $-10.37^{* * *}$ & $-10.44 * * *$ \\
\hline & $(0.765)$ & $(0.765)$ & $(0.564)$ & $(0.564)$ & $(0.505)$ & $(0.505)$ \\
\hline \multirow{2}{*}{ EXEMPT X FOREIGN } & $2.394 *$ & $2.184 *$ & $2.332^{* * *}$ & $2.297 * *$ & $3.802 * * *$ & $4.326^{* * *}$ \\
\hline & $(0.944)$ & $(0.955)$ & $(0.694)$ & $(0.710)$ & $(0.613)$ & $(0.623)$ \\
\hline \multirow{2}{*}{ RETURN } & $0.943^{* * *}$ & $0.947 * * *$ & $0.960 * * *$ & $0.961 * * *$ & $0.521^{* * *}$ & $0.483^{* * *}$ \\
\hline & $(0.181)$ & $(0.181)$ & $(0.146)$ & $(0.146)$ & $(0.105)$ & $(0.105)$ \\
\hline \multirow{2}{*}{ RISK } & -0.009 & 0.044 & -0.021 & -0.016 & $-0.0417^{*}$ & $-0.0956 * * *$ \\
\hline & $(0.031)$ & $(0.047)$ & $(0.022)$ & $(0.033)$ & $(0.0168)$ & $(0.0204)$ \\
\hline \multirow{2}{*}{ SIZE } & $1.144^{* * *}$ & $1.140 * * *$ & $1.093^{* * *}$ & $1.092 * * *$ & $1.079 * * *$ & $1.087^{* * *}$ \\
\hline & $(0.093)$ & $(0.093)$ & $(0.069)$ & $(0.069)$ & $(0.0612)$ & $(0.0612)$ \\
\hline \multirow{2}{*}{ FEE } & $2.362 * * *$ & $2.315^{* * *}$ & $2.515^{* * *}$ & $2.511^{* * *}$ & $2.626 * * *$ & $2.705^{* * *}$ \\
\hline & $(0.247)$ & $(0.249)$ & $(0.183)$ & $(0.184)$ & $(0.159)$ & $(0.160)$ \\
\hline \multirow{2}{*}{$A G E$} & $-0.358^{* *}$ & $-0.340 * *$ & $-0.473^{* * *}$ & $-0.471^{* * *}$ & $-0.528 * * *$ & $-0.563^{* * *}$ \\
\hline & $(0.124)$ & $(0.124)$ & $(0.092)$ & $(0.092)$ & $(0.0802)$ & $(0.0805)$ \\
\hline \multirow{2}{*}{$B I G$} & $1.825^{* * *}$ & $1.807 * * *$ & $1.716^{* * *}$ & $1.714 * * *$ & $1.603 * * *$ & $1.648^{* * *}$ \\
\hline & $(0.407)$ & $(0.407)$ & $(0.302)$ & $(0.302)$ & $(0.263)$ & $(0.263)$ \\
\hline \multirow{2}{*}{$F X$} & 40.54 & 47.90 & -8.633 & -7.995 & 12.18 & 23.21 \\
\hline & $(74.06)$ & $(74.23)$ & $(42.56)$ & $(42.65)$ & $(27.27)$ & $(27.36)$ \\
\hline \multirow{2}{*}{$B M$} & $-0.849 * * *$ & $-0.842 * * *$ & $-0.795^{* * *}$ & $-0.794 * * *$ & $-0.370 * * *$ & $-0.344^{* *}$ \\
\hline & $(0.209)$ & $(0.209)$ & $(0.149)$ & $(0.149)$ & $(0.107)$ & $(0.107)$ \\
\hline \multirow{2}{*}{ Sharpe } & & -0.379 & & -0.0375 & & $0.538^{* * *}$ \\
\hline & & $(0.260)$ & & $(0.160)$ & & $(0.115)$ \\
\hline SOper & \multicolumn{6}{|c|}{ Included } \\
\hline Adj. $R$-sq & 0.0692 & 0.0693 & 0.0638 & 0.0637 & 0.0563 & 0.0572 \\
\hline F-stat. & $59.58^{* * *}$ & $54.80^{* * *}$ & $97.94^{* * *}$ & $89.78^{* * *}$ & $119.5^{* * *}$ & $111.5^{* * *}$ \\
\hline Observations & 8,669 & 8,669 & 15,655 & 15,655 & 21,874 & 21,874 \\
\hline
\end{tabular}

Notes: Period 1 = May 1, 2007 to June 30, 2007; Period 2 = April 1, 2007 to July 31, 2007; Period 3 = March 1, 2007 to August $31,2007 . * *, * *$ and $*$ indicate statistical significance at the $1 \%, 5 \%$, and $10 \%$ two-tailed level, respectively. The definition of variables is given in the note to Table 4.

Table 7. Regression results: RSTA 2016

\begin{tabular}{|c|c|c|c|c|c|c|}
\hline \multirow{2}{*}{ Variables } & \multicolumn{2}{|c|}{ Period 1} & \multicolumn{2}{|c|}{ Period 2} & \multicolumn{2}{|c|}{ Period 3} \\
\hline & Model 1 & Model 2 & Model 1 & Model 2 & Model 1 & Model 2 \\
\hline \multirow{2}{*}{ EXEMPT } & 0.158 & 0.0551 & 0.266 & -0.0279 & 0.338 & 0.161 \\
\hline & $(0.350)$ & $(0.356)$ & $(0.210)$ & $(0.215)$ & $(0.175)$ & $(0.177)$ \\
\hline \multirow{2}{*}{ FOREIGN } & $-23.21^{* * *}$ & $-22.94^{* * *}$ & $-23.85^{* * *}$ & $-23.41^{* * *}$ & $-23.55^{* * *}$ & $-23.22^{* * *}$ \\
\hline & $(0.383)$ & $(0.418)$ & $(0.234)$ & $(0.243)$ & $(0.207)$ & $(0.215)$ \\
\hline \multirow{2}{*}{ EXEMPT X FOREIGN } & $0.950^{*}$ & 0.691 & $1.704^{* * *}$ & $1.270^{* * *}$ & $1.767^{* * *}$ & $1.470^{* * *}$ \\
\hline & $(0.471)$ & $(0.497)$ & $(0.303)$ & $(0.310)$ & $(0.262)$ & $(0.267)$ \\
\hline \multirow{2}{*}{ RETURN } & $-0.532 * * *$ & $-0.553^{* * *}$ & $-0.346 * * *$ & $-0.401^{* * *}$ & $-0.132 * * *$ & $-0.174 * * *$ \\
\hline & $(0.057)$ & $(0.058)$ & $(0.042)$ & $(0.043)$ & $(0.0362)$ & $(0.037)$ \\
\hline \multirow{2}{*}{ RISK } & $-0.141^{* * *}$ & $-0.125^{* * *}$ & $-0.103^{* * *}$ & $-0.062 * * *$ & $-0.089 * * *$ & $-0.059 * * *$ \\
\hline & $(0.014)$ & $(0.017)$ & $(0.009)$ & $(0.0101)$ & $(0.008)$ & $(0.009)$ \\
\hline \multirow{2}{*}{ SIZE } & $0.419 * * *$ & $0.420 * * *$ & $0.411^{* * *}$ & $0.409 * * *$ & $0.410^{* * *}$ & $0.410 * * *$ \\
\hline & $(0.036)$ & $(0.036)$ & $(0.024)$ & $(0.024)$ & $(0.021)$ & $(0.021)$ \\
\hline \multirow{2}{*}{ FEE } & $3.523 * * *$ & $3.540 * * *$ & $3.407 * * *$ & $3.448 * * *$ & $3.339 * * *$ & $3.367^{* * *}$ \\
\hline & $(0.158)$ & $(0.158)$ & $(0.105)$ & $(0.105)$ & $(0.091)$ & $(0.091)$ \\
\hline \multirow{2}{*}{$A G E$} & $0.108 * * *$ & $0.103^{* *}$ & $0.098^{* * *}$ & $0.086^{* * *}$ & $0.087 * * *$ & $0.077^{* * *}$ \\
\hline & $(0.033)$ & $(0.033)$ & $(0.022)$ & $(0.022)$ & $(0.019)$ & $(0.019)$ \\
\hline
\end{tabular}


Table 7 (cont.). Regression results: RSTA 2016

\begin{tabular}{|c|c|c|c|c|c|c|}
\hline \multirow{2}{*}{ Variables } & \multicolumn{2}{|c|}{ Period 1} & \multicolumn{2}{|c|}{ Period 2} & \multicolumn{2}{|c|}{ Period 3} \\
\hline & Model 1 & Model 2 & Model 1 & Model 2 & Model 1 & Model 2 \\
\hline \multirow{2}{*}{$B I G$} & $6.407 * * *$ & $6.421 * * *$ & $6.285 * * *$ & $6.312 * * *$ & $6.348 * * *$ & $6.374 * * *$ \\
\hline & $(0.226)$ & $(0.226)$ & $(0.149)$ & $(0.149)$ & $(0.129)$ & $(0.129)$ \\
\hline$F X$ & $\begin{array}{l}-1.150 \\
(8.594)\end{array}$ & $\begin{array}{l}-2.315 \\
(8.623)\end{array}$ & $\begin{array}{c}3.447 \\
(6.184)\end{array}$ & $\begin{array}{c}0.669 \\
(6.197)\end{array}$ & $\begin{array}{c}9.417 \\
(5.001)\end{array}$ & $\begin{array}{c}8.914 \\
(5.001)\end{array}$ \\
\hline \multirow{2}{*}{$B M$} & $0.535^{* * *}$ & $0.533^{* * *}$ & $0.360^{* * *}$ & $0.364^{* * *}$ & $0.144^{* * *}$ & $0.147^{* * *}$ \\
\hline & $(0.0603)$ & $(0.06)$ & $(0.045)$ & $(0.045)$ & $(0.038)$ & $(0.038)$ \\
\hline \multirow{2}{*}{ Sharpe } & & 0.0615 & & $0.152 * * *$ & & $0.110 * * *$ \\
\hline & & $(0.038)$ & & $(0.023)$ & & $(0.019)$ \\
\hline SOper & \multicolumn{6}{|c|}{ Included } \\
\hline Adj. R-sq & 0.2342 & 0.2342 & 0.2338 & 0.2341 & 0.2274 & 0.2276 \\
\hline F-stat. & $1066.7^{* * *}$ & $978.1^{* * *}$ & $2397.8^{* * *}$ & $2202.7^{* * *}$ & $3103.0^{* * *}$ & $2847.9 * * *$ \\
\hline Observations & \multicolumn{2}{|c|}{38,334} & \multicolumn{2}{|c|}{86,420} & \multicolumn{2}{|c|}{115,910} \\
\hline
\end{tabular}

Notes: Definition of periods is as follows. Period 1 = February 1, 2016 to March 31, 2016; Period 2 = January 1, 2016 to April 30, 2016; Period $3=$ December 1, 2015 to May 31, 2016. ***,** and * indicate statistical significance at the $1 \%, 5 \%$, and $10 \%$ two-tailed level, respectively. The definition of variables is given in the note to Table 4.

\section{DISCUSSION}

The empirical findings in Section 3 are in line with prior studies' suggestions and provide further supporting evidence. The prior literature evidenced fund managers' consideration of investors' tax burden indirectly by showing the after-tax return or fund financial statement ratio from a cross-sectional analysis. In addition to the findings from prior studies, this study shows a significant change in movement of investment asset allocation in a fund at the time of implementation of a temporary tax relief and provides further evidence on how a fund manager takes action to enhance investors' after-tax returns.

Moreover, these findings can be interpreted in the context of prior studies dealing with a fund management company's reputation and the spillover effect (Gjergji et al., 2017; Sialm \& Tham, 2016). There are other stakeholders around investment funds, such as the fund distributor, the fund administrator and custodian, in addition to the fund manager and fund investor. Fund distributors (e.g. bank, brokerage firms), who channel money to a fund from investors, may be sensitive to these tax amendments because they are withholding agents on distributions made to the investors under the Korean tax law. In this regard, as intermediaries between fund managers and fund investors, they may further inform fund managers regarding tax developments because fund distributors are liable for the penalties for unduly withheld tax on dividends if there is an error in tax withholding. Fund administrators also need to be aware of tax developments because they are required to calculate and release tax NAV (Tax NAV is calculated by excluding capital gains on domestic shares under the Individual Income Tax Act. In the wake of the RSTA 2007 and the RSTA 2016, the tax NAV needs be calculated by excluding the capital gains on both domestic and foreign shares.), which is the basis for determining the taxable dividend. In such an environment, fund managers may be more informed about temporary tax amendments because they are surrounded by other stakeholders.

\section{CONCLUSION}

The aim of this study is to investigate whether fund managers change asset allocation style depending on the type of funds being managed for tax purposes when temporary tax relief laws on investment funds are implemented. To do this, the study reviews the change in the ratio of tax-favored assets (i.e., overseas-listed shares) to the NAV of a tax relief qualified fund around the implementation dates of tax relief rules in 2007 and 2016. 
It was found that the ratio of the value of the tax-favored asset to NAV in the tax relief qualified fund increased significantly in the period following the implementation of the tax relief rule in both 2007 and 2016. With respect to RSTA 2007, overseas equity funds show an increased equity portion in NAV after the enforcement date (June 1,2007) during all the tested periods (Periods 1,2, and 3). The study also found the same pattern around the enforcement date of RSTA 2016, except for one month before and after the enforcement date (March 1, 2016), and that the ratio of domestic equity value in domestic equity funds decreased significantly, unlike the ratio of overseas equity value in overseas equity funds.

These findings imply that fund managers are likely to shift their portfolio focus to emerging tax-favored assets to provide fund investors with tax-saving opportunities that may arise from a fund if a tax amendment introduces new tax breaks on the investment assets. They also tend to reduce exposure to other investments that are not eligible for tax relief under the law. This means that a fund manager considers a fund investor's after-tax return and tries to take advantage of tax-saving opportunities if there is any tax amendment that provides such opportunities.

This study contributes to the existing literature by providing empirical evidence that the investment asset allocation in a fund may change because of the tax factor derived from temporary tax relief. Given that prior literature on the effect of taxation on funds has been heavily concentrated on the relationship between fund investors' tax clientele and fund performance by comparing taxable accounts and non(less)-taxable accounts, this study shows that there is a significant shift in asset allocation in funds around the time of a tax amendment. In this regard, this study distinguishes itself from prior literature by providing more direct evidence on how a fund manager would make a change to his/her fund management style by considering tax factors for investors. These findings complement prior studies that argue that fund managers consider fund investors after a tax return in the management of his/her portfolio.

\section{AUTHOR CONTRIBUTIONS}

Conceptualization: Hyeongtae Cho.

Data curation: Hyeongtae Cho.

Formal analysis: Hyeongtae Cho.

Investigation: Hyeongtae Cho.

Methodology: SungMan Yoon.

Project administration: SungMan Yoon.

Resources: Hyeongtae Cho.

Software: Hyeongtae Cho.

Supervision: SungMan Yoon.

Validation: SungMan Yoon.

Visualization: SungMan Yoon.

Writing - original draft: Hyeongtae Cho.

Writing - review \& editing: SungMan Yoon.

\section{ACKNOWLEDGMENT}

This work was supported by the Ministry of Education of the Republic of Korea and the National Research Foundation of Korea (NRF- 2019S1A5A8035027). 


\section{REFERENCES}

1. Adcock, C., Nelson, A., Cortez, M. C., Oliveira, B., \& Silva, F. (2020). Does the choice of fund performance measure matter? Investment Analysts Journal, 49(1), 53-77. https://doi.org/10.1080/102 93523.2020.1723865

2. Akpanibah, E. E., \& Ini, O. U. (2019). Portfolio Selection Strategies with Return Clause in a DC Pension Fund. Asian Research Journal of Mathematics, 15(3), 1-15. https://doi.org/10.9734/arjom/2019/v15i330149

3. Bergstresser, D., \& Poterba, J. (2002). Do after-tax returns affect mutual fund inflows? Journal of Financial Economics, 63, 381-414. https://doi.org/10.1016/S0304405X(02)00066-1

4. Chan, A., \& Chen, C. R. (1992). How Well do Asset Allocation Mutual Fund Managers Allocate Assets? The Journal of Portfolio Management, 18(3), 81-91. https:// doi.org/10.3905/jpm.1992.81

5. Christoffersen, S. E. K., Ge'czyb, C. C., Mustob, D. K., \& Reed, A. V. (2005). Cross border dividend taxation and the preferences of taxable and non-taxable investors: Evidence from Canada. Journal of Financial Economics, 78, 121-144. https://doi.org/10.1016/j.jfineco.2004.08.004

6. Cho, H. T. (2018). A study on the effect of the revision of income tax on fund investment focusing on deferral of gain on disposal of underlying assets. Journal of Taxation Research, 35(4). (In Korean). Retrieved from http:// www.koreataxation.org/

7. Cho, H. T., \& Yoon, S. M. (2016). The effect of tax clientele for fund investment on fund manager's behavior in fund market: The case of Korea. International Journal of Applied Engineering Research, 11(9), 6817-6823. Retrieved from https://www.ripublication.com/ ijaer.htm

8. Desai, M. A., \& Dharmapala, D. (2007). Taxes and portfolio choice: Evidence from JGTRRA'S treatment of international dividends (NBER
Working Paper). https://doi.

org/10.3386/w13281

9. Desai, M. A., \& Dharmapala, D. (2011). Dividend taxes and international portfolio choice. The Review of Economics and Statistics, 93(1), 266. http://dx.doi. org/10.2139/ssrn.1000680

10. Ferson, W., \& Mo, H. (2016). Performance measurement with selectivity, market and volatility timing. Journal of Financial Economics, 121(1), 93-110. https://doi.org/10.1016/j.jfineco.2016.02.012

11. Fong, K. Y. L., David, R. G., Sarah, S. W. L, \& Peter, L. S. (2009). Do active fund managers care about capital gains tax efficiency? PacificBasin Finance Journal, 17, 257-270. https://doi.org/10.1016/j.pacfin.2008.04.002

12. Gjergji, C., Alexander, K., \& Christoph, S. (2017). Do Financial Advisors Provide Tangible Benefits for Investors? Evidence from TaxMotivated Mutual Fund Flows. Review of Finance, 21(2), 637665. http://dx.doi.org/10.2139/ ssrn. 2177401

13. Guan, J. X., Li, O. Z., \& Ma, J. (2008). Managerial ability and the shareholder tax sensitivity of dividends. Journal of Financial and Quantitative Analysis, 53(1), 335-364. https://doi.org/10.1017/ S0022109017001004

14. Li, H., Xu, Y., \& Zhang, X. (2016). Hedge fund performance evaluation under the stochastic discount factor framework. Journal of Financial and Quantitative Analysis, 51(1), 231-257. https://doi.org/10.1017/ S0022109016000120

15. Scholes, M. S., Wolfson, M. A., Erickson, M. M., Maydew, E. L., Hanlon, M. L., \& Shevlin, T. (2016). Taxes and Business Strategy: A Planning Approach (5th ed.). London: Pearson Education.

16. Sialm, C., \& Starks, L. (2012). Mutual fund tax clienteles. The Journal of Finance, 67(4), 1397-
1422. https://doi.org/10.1111/

j.1540-6261.2012.01751.x

17. Sialm, C., \& Tham, T. M. (2016). spillover effects in mutual fund companies. Management Science, 62(5), 1472-1486. https://doi. org/10.1287/mnsc.2015.2200

18. Sialm, C., \& Zhang H. (2020). Tax-efficient asset management: evidence from equity mutual funds. The Journal of Finance, 75(2), 735-777. https://doi. org/10.1111/jofi.12843

19. Yoon, S. M. (2014). Do Mutual Fund Investors Consider Capital Gain Taxes? Evidence from Korea. Korean Journal of Taxation Research, 31(1), 45-72. (In Korean). Retrieved from http:// www.koreataxation.org/

20. Yoon, S. M., \& Kim, N. C. (2015). Effect of Tax Reform for Onshore Funds on Tax Burden of Investor: Evidence from Korean Market. Research Journal of Business Management, 9, 335349. https://doi.org/10.3923/ rjbm.2015.335.349 